\title{
The Role of Metal Ions in Protein and Fatty Acids Biosynthesis in Soybean under Micronutrients Application to Soil
}

\author{
Mudlagiri B. Goli1 ${ }^{*}$, Pande Manju${ }^{1}$, Kibet Daniel ${ }^{1}$, Nacer Bellaloui ${ }^{2}$, Daniele De Wrachien ${ }^{3}$ \\ ${ }^{1}$ Natural Sciences and Environmental Heath, Mississippi Valley State University, Itta Bena, MS, USA \\ ${ }^{2}$ USDA, Agricultural Research Service, Crop Genetics Research Unit, Stoneville, MS, USA \\ ${ }^{3}$ Department of Agricultural Engineering, State University, Milan, Italy \\ Email: *emby1234@gmail.com
}

How to cite this paper: Goli, M.B., Manju, P., Daniel, K., Bellaloui, N. and De Wrachien, D. (2018) The Role of Metal Ions in Protein and Fatty Acids Biosynthesis in Soybean under Micronutrients Application to Soil. Agricultural Sciences, 9, 741-749. https://doi.org/10.4236/as.2018.96052

Received: May 10, 2018

Accepted: June 24, 2018

Published: June 27, 2018

Copyright $\odot 2018$ by authors and Scientific Research Publishing Inc. This work is licensed under the Creative Commons Attribution International License (CC BY 4.0).

http://creativecommons.org/licenses/by/4.0/

(c) (i) Open Access

\begin{abstract}
The present study is part of our ongoing investigation to study the role of trace elements on soybean seed composition (protein, oil, and fatty acids). This study was conducted to study the effects of five trace elements $(\mathrm{Mn}, \mathrm{Cu}$, $\mathrm{Zn}, \mathrm{Mo}, \mathrm{B})$. The treatments of $\mathrm{Mn}, \mathrm{Cu}, \mathrm{Zn}, \mathrm{Mo}$, and B were chlorides, except $\mathrm{Mo}$ as oxide, and $\mathrm{B}$ as boric acid. The treatments were $\mathrm{Mn}, \mathrm{Cu}, \mathrm{Zn}, \mathrm{Mo}$, and $\mathrm{B}$ alone and in combination with the chelating agent citric acid (CA), for example $\mathrm{Mn}+\mathrm{CA}, \mathrm{Cu}+\mathrm{CA}$, and $\mathrm{Zn}+\mathrm{CA}$. Soybean cultivar (Bolivar with maturity group V) was grown in a repeated greenhouse experiment in a randomized complete block design. The compounds were applied to three-week-old soybean plants at V3 (vegetative) and at R3 (beginning of seed-pod initiation) stages. The plants were allowed to grow until maturity under greenhouse conditions. The harvested seeds were analyzed for mineral, protein, and fatty acid contents. Results showed that $\mathrm{Mn}, \mathrm{Cu}$, and $\mathrm{B}$ treatments increased seed protein, while $\mathrm{Zn}, \mathrm{Mo}, \mathrm{Cu}+\mathrm{CA}$, and $\mathrm{B}+\mathrm{CA}$ decreased the protein. Treatments of $\mathrm{Zn}, \mathrm{Mo}, \mathrm{CA}, \mathrm{Cu}+\mathrm{CA}, \mathrm{Zn}+\mathrm{CA}, \mathrm{Mo}+\mathrm{CA}$, and $\mathrm{B}+\mathrm{CA}$ increased the oil. Treatments of $\mathrm{Mn}$ and $\mathrm{Cu}$ decreased the oil. The $\mathrm{Cu}$ and $\mathrm{B}$ treatments increased oleic acid by $8.0 \%$ and $7.4 \%$, respectively for $\mathrm{Cu}$ and $\mathrm{B}$. Treatments of $\mathrm{Mn}, \mathrm{Mo}, \mathrm{CA}$, and $\mathrm{Mn}+\mathrm{CA}, \mathrm{Cu}+\mathrm{CA}, \mathrm{Zn}+\mathrm{CA}, \mathrm{Mo}+\mathrm{CA}$, and $\mathrm{B}+\mathrm{CA}$ decreased oleic acid by $0.6 \%$ to $14.4 \%$. Treatments of $\mathrm{Cu}, \mathrm{Zn}, \mathrm{Mo}, \mathrm{B}, \mathrm{CA}, \mathrm{Mn}$ and their combination with CA increased linoleic acid by $1.3 \%$ to $6.5 \%$. Our goal was to identify the trace elements that would make desirable alteration in the seed composition qualities.
\end{abstract}

\section{Keywords}

Soybean, Cu, Mn, Zn, Mo and B, Citric Acid (CA), Protein, Oil and Fatty Acids 


\section{Introduction}

Soybean is an important source of plant-based protein for humans and animal feed. The seeds contain significant amount of protein, dietary minerals and vitamins. Soybean oil is another valuable product used in industrial food application. United states account for 36.7\% [1] [2] [3] of world soybean crop. In recent years, micronutrient deficiency is reported in calcareous soil as well as all over the world [4] [5] [6], affecting crop yield. It is also reported that deficiencies of trace elements have a significant influence on soybean seed quality and yield [7]. The micronutrient nutrient iron $(\mathrm{Fe})$ is a necessary element involved in many redox reactions of photosynthesis and respiration, and important for normal soybean growth [8]. Similarly, recent research has also demonstrated that small amounts of micronutrients like $\mathrm{Zn}, \mathrm{Fe}$, and $\mathrm{Mn}$ application increase significantly the yield of crops [9] [10] [11] [12]. Fe, Mn and $\mathrm{Zn}$ have an important role in various enzymatic reactions: for example, $\mathrm{Mn}$ has an important role in electron transfer, activates decarboxylase and dehydrogenase, and is a constituent of complex PSII protein [13], and chlorophyll production. Zn has vital role in several enzymatic reactions and is important in protein and carbohydrate synthesis, and in wide range of processes. Similarly, $\mathrm{Mo}, \mathrm{Cu}$ and $\mathrm{B}$ are other important microelements utilized by several enzymes and required for plant development and growth. Earlier, we studied the effect of $\mathrm{Fe}$ and $\mathrm{Fe}$ in combination treatment with chelating agents (citric acid, salicylic acid, and EDTA) on seed mineral, protein, oil and fatty acid contents in soybean [14]. It was reported combinations of chelating agents can increase iron availability and thus may improve seed constituents [15]. However, there is limited research on the effect of micro nutrient soil application on soybean plants and its effect on seed quality. Therefore, the present study was undertaken to investigate the effect of soil applications of five micronutrients, $\mathrm{Cu}, \mathrm{Mn}, \mathrm{Zn}, \mathrm{B}$, Moalone and in combination with chelating agent Citric Acid (CA) for better absorption of metal elements in the plant system. The first study of the above micro nutrient applications and the effect on mineral nutrient acquisition by the soybean seeds was published earlier [16]. In the second part of this research, our focus was to study the effect of the micronutrient application on seed protein, oil and fatty acids. Here, we are briefly enumerating the results of that research work related to formation of protein, oil and fatty acids in soybean seeds.

Our hypothesis was that possibly by using different concentrations of trace mineral applications, we may be able to modulate seed quality in order to achieve desirable fatty acid composition and protein content in seeds.

\section{Material and Methods}

A greenhouse experiment was conducted at Mississippi Valley State University, Itta Bena, Mississippi, USA (latitude of N $33^{\circ} 28^{\prime}$ and longitude W $90^{\circ} 20^{\prime}$ ). Soybean cultivar Bolivar (maturity group V) was planted in 48 pots (4 gallon). The pots were divided and labeled into 11 treatment groups + Control (C), Mn (T1), 
$\mathrm{Cu}$ (T2, Zn (T3), Mo (T4), B (T5), CA (T6), Mn + CA (T7), Cu + CA (T8), Zn + CA (T9), Mo + CA (T10), and B + CA (T11). Four replicates were used for each treatment. Pots were arranged in a randomized complete block design. The planting of six seeds in each pot was done in early June 2013. The top soil used for this experiment was analyzed for mineral concentrations $(\mathrm{mg} / \mathrm{kg})$ which were: $\mathrm{Na}=41.7, \mathrm{Mn}=204.6, \mathrm{Cu}=0.5, \mathrm{Fe}=4185, \mathrm{Zn}=27.5, \mathrm{Mo}=0.5, \mathrm{~B}=2.6$. The macro-nutrients were $\mathrm{K}=1469, \mathrm{Ca}=4491, \mathrm{Mg}=838, \mathrm{P}=257, \mathrm{~S}=427$. Ten days after germination, soybean seedlings were watered twice a week. To prepare the solution, $2.4 \mathrm{mmol}$ of the compounds, $\mathrm{MnCl}_{2}, \mathrm{CuCl}_{2}, \mathrm{ZnCl}_{2}, \mathrm{MoO}_{3}$, and $\mathrm{H}_{3} \mathrm{BO}_{3}$ were dissolved in $1000 \mathrm{ml}$ of deionized water (DI). Then, $125 \mathrm{ml}(0.30$ $\mathrm{mmol}$ ) of the solution were used per pot. The chelating agent CA was prepared by dissolving $7.8 \mathrm{mmol}$ of CA in $2000 \mathrm{ml}$ of DI water. The $76 \mathrm{ml}$ of this CA solution was applied to each pot. The micro-nutrients were applied to pots (soil application) as separate or in combination.

\subsection{Treatments}

Briefly, the minerals were applied twice, one week apart, at V3 stage of soybean plants. The pots were watered twice a week. The plants were grown under greenhouse conditions of natural light and temperature. The soybean plants were treated with the nutrient application once again during R3 (pod initiation stage). The plants in each pot were then grown until maturity (3rd week of October). The temperature in the greenhouse throughout this experiment varied from $32.2^{\circ} \mathrm{C}$ to $35^{\circ} \mathrm{C}$. Mature seeds were harvested at R8 (full maturity stage) for chemical analyses.

\subsection{Experimental Design and Statistical Analyses}

The experiment was a randomized complete block design. Four replicates were used for each treatment. Analysis of variance was conducted using Proc GLM in SAS [17]. Means were separated using Fisher's Least Significant Difference test using $5 \%$ as level of significance.

\subsection{Seed Protein, Oil, and Fatty Acid Analysis}

Mature seeds from each soybean pot were sampled and analyzed for protein, oil and fatty acids using near-infrared (NIR)reflectance diode array feed analyzer (Perten, Spring Field, IL, USA) [18]. Calibration curves have been regularly updated for unique samples according to AOAC methods [19] [20]. Protein and oil were calculated based on dry weight; fatty acids were expressed on total oil basis. Analysis of Variance was conducted using Proc GLM in SAS [17]. Means were separated using Fisher's least significant difference test using 5\% as level of Significance.

\section{Results}

Seed Protein, Oil, and Fatty Acid composition (Table 1 and Table 2). 
Table 1. Effects of trace elements on seed protein, oil and fatty acids after chemical treatment. $\mathrm{C}$ is control and the rest of the chemicals are applied as chlorides, except Mo $\left(\mathrm{MoO}_{3}\right)$ and Citric acid (CA) and $\mathrm{B}$ (Boric Acid, $\mathrm{H}_{3} \mathrm{BO}_{3}$ ).

\begin{tabular}{|c|c|c|c|c|c|c|c|}
\hline Treatment & Proteins & Oil & $\begin{array}{c}\text { Palmitic } \\
(16: 0)\end{array}$ & Stearic $(18: 0)$ & $\begin{array}{c}\text { Oleic } \\
(18: 1)\end{array}$ & $\begin{array}{c}\text { Linoleic } \\
(18: 2)\end{array}$ & $\begin{array}{c}\text { linolenic } \\
(18: 3)\end{array}$ \\
\hline $\mathrm{C}$ & $40.067 \mathrm{~cd}$ & $19.8 \mathrm{~d}$ & $10.3 \mathrm{de}$ & $4.23 \mathrm{~cd}$ & $38 \mathrm{bc}$ & $49 \mathrm{f}$ & $3.35 \mathrm{ef}$ \\
\hline $\mathrm{T} 1(\mathrm{Mn})$ & $\begin{array}{c}41.63 \mathrm{a} \\
(+3.9)\end{array}$ & $19.57 \mathrm{~d}$ & $10.47 \mathrm{~cd}$ & $4.27 \mathrm{bcd}$ & $37.8 \mathrm{bc}$ & $49.2 \mathrm{f}$ & $3.1 \mathrm{ef}$ \\
\hline $\mathrm{T} 2(\mathrm{Cu})$ & $41.25 \mathrm{abc}$ & $\begin{array}{l}18.6 \mathrm{e} \\
(+6.4)\end{array}$ & $\begin{array}{l}8.4 \mathrm{~h} \\
(-18.4)\end{array}$ & $\begin{array}{l}4.0 \mathrm{fg} \\
(-5.4)\end{array}$ & $\begin{array}{l}41.1 \mathrm{a} \\
(+8.2)\end{array}$ & 49.9 ef & $\begin{array}{c}1.8 \mathrm{~h} \\
(-46.3)\end{array}$ \\
\hline $\mathrm{T} 3(\mathrm{Zn})$ & $40.367 \mathrm{de}$ & $\begin{array}{c}20.63 b c \\
(+3.82)\end{array}$ & $10.07 \mathrm{ef}$ & $4.27 \mathrm{bcd}$ & $37.37 \mathrm{bc}$ & $49.78 \mathrm{f}$ & $\begin{array}{l}4.35 \mathrm{~cd} \\
(+29.9)\end{array}$ \\
\hline $\mathrm{T} 4(\mathrm{Mo})$ & $\begin{array}{c}38.38 \mathrm{e} \\
(-4.2)\end{array}$ & $\begin{array}{c}20.85 \mathrm{ab} \\
(+4.9)\end{array}$ & $\begin{array}{c}10.825 \mathrm{bc} \\
(+5.1)\end{array}$ & $4.35 \mathrm{cb}$ & $\begin{array}{l}34 \mathrm{de} \\
(-10.5)\end{array}$ & $\begin{array}{c}51.05 \text { cde } \\
(+4.2)\end{array}$ & $\begin{array}{l}4.35 \mathrm{~cd} \\
(+29.9)\end{array}$ \\
\hline $\mathrm{T} 5(\mathrm{~B})$ & $\begin{array}{l}41.8 \mathrm{a} \\
(+4.3)\end{array}$ & $\begin{array}{c}17.1 \mathrm{f} \\
(-13.9)\end{array}$ & $\begin{array}{c}9.2 \mathrm{~g} \\
(-10.7)\end{array}$ & $3.9 \mathrm{~g}(-7.8)$ & $\begin{array}{l}40.8 \mathrm{a} \\
(+7.4)\end{array}$ & $49.5 \mathrm{f}$ & \\
\hline T6(CA) & $\begin{array}{l}38.4 \mathrm{e} \\
(-4.2)\end{array}$ & $\begin{array}{c}21.1 \mathrm{ab} \\
(+6.2)\end{array}$ & $10.53 \mathrm{~cd}$ & $\begin{array}{l}4.38 \mathrm{~b} \\
(+3.5)\end{array}$ & $\begin{array}{l}33.45 \mathrm{e} \\
(-12.0)\end{array}$ & $\begin{array}{c}51.62 \mathrm{cde} \\
(+5.3)\end{array}$ & $3.35 \mathrm{ef}$ \\
\hline $\begin{array}{c}\mathrm{T} 7 \\
(\mathrm{Mn}+\mathrm{CA})\end{array}$ & $40.075 \mathrm{~cd}$ & $19.85 \mathrm{~d}$ & $\begin{array}{l}9.75 \mathrm{f} \\
(-5.3)\end{array}$ & $4.18 \mathrm{de}$ & $36.32 \mathrm{~cd}$ & $50.43 \mathrm{def}$ & $3 \mathrm{fg}$ \\
\hline $\begin{array}{c}\mathrm{T} 8 \\
(\mathrm{Cu}+\mathrm{CA})\end{array}$ & $\begin{array}{c}37.98 \text { e } \\
(-5.2)\end{array}$ & $\begin{array}{c}21.38 \mathrm{ab} \\
(+7.6)\end{array}$ & $\begin{array}{l}11.3 \mathrm{a} \\
(+9.7)\end{array}$ & $4.18 \mathrm{de}$ & $\begin{array}{l}28.75 \mathrm{fg} \\
(-24.3)\end{array}$ & $\begin{array}{c}52.33 \mathrm{abc} \\
\quad(+6.8)\end{array}$ & $\begin{array}{c}4.83 \mathrm{c} \\
(+44.0)\end{array}$ \\
\hline $\begin{array}{c}\mathrm{T} 9 \\
(\mathrm{Zn}+\mathrm{CA})\end{array}$ & $\begin{array}{c}37.98 \mathrm{e} \\
(-5.2)\end{array}$ & $\begin{array}{c}20.77 \mathrm{ab} \\
(+4.5)\end{array}$ & $10.47 \mathrm{~cd}$ & $4.18 \mathrm{de}$ & $36.43 \mathrm{~cd}$ & $50.1 \mathrm{ef}$ & $2.93 \mathrm{fg}$ \\
\hline $\begin{array}{c}\mathrm{T} 10 \\
(\mathrm{Mo}+\mathrm{CA})\end{array}$ & $\begin{array}{c}37.98 \mathrm{e} \\
(-5.2)\end{array}$ & $\begin{array}{c}21.43 \mathrm{a} \\
(+7.9)\end{array}$ & $\begin{array}{c}11.2 \mathrm{ab} \\
(+8.7)\end{array}$ & $4.18 \mathrm{de}$ & $\begin{array}{l}29.38 \mathrm{f} \\
(-22.7)\end{array}$ & $\begin{array}{c}52.28 \mathrm{abc} \\
(+6.7)\end{array}$ & $\begin{array}{c}5.75 \mathrm{~b} \\
(+71.6)\end{array}$ \\
\hline $\begin{array}{c}\text { T11 } \\
(B+C A)\end{array}$ & $\begin{array}{c}37.98 \mathrm{e} \\
(-5.2)\end{array}$ & $\begin{array}{c}20.83 \mathrm{ab} \\
(+4.8)\end{array}$ & $10.23 \mathrm{de}$ & $4.18 \mathrm{de}$ & $\begin{array}{c}32.7 \mathrm{e} \\
(-14.0)\end{array}$ & $52.4 \mathrm{f}$ & $3.43 \mathrm{def}$ \\
\hline $\begin{array}{c}\mathrm{T} 12 \\
(\mathrm{KCl})\end{array}$ & $\begin{array}{c}42.2 \mathrm{a} \\
(+5.3 \%)\end{array}$ & $\begin{array}{l}17.2 \mathrm{f} \\
(-13.1)\end{array}$ & $10.2 \mathrm{~d}$ & $\begin{array}{l}4.1 \text { ef } \\
(-3.0)\end{array}$ & $\begin{array}{l}40.9 \mathrm{a} \\
(+7.6)\end{array}$ & $\begin{array}{l}46.6 \mathrm{~g} \\
(-4.9)\end{array}$ & $\begin{array}{l}2.1 \mathrm{gh} \\
(-37.3)\end{array}$ \\
\hline $\begin{array}{c}\mathrm{T} 13 \\
(\mathrm{KCl}+\mathrm{CA})\end{array}$ & $\begin{array}{c}41.2 \mathrm{ab} \\
(+2.8)\end{array}$ & $19.8 \mathrm{~d}$ & $10.3 \mathrm{~d}$ & $\begin{array}{c}4.8 \mathrm{a} \\
(+13.5)\end{array}$ & $39.7 \mathrm{ab}$ & $49.7 \mathrm{f}$ & \\
\hline
\end{tabular}

Notes: Means given within a column bearing the same letter like the control are not significantly different at $\mathrm{p}<0.05$. The numbers in the brackets with $\%$ are the percentage changes increase or decrease in seed composition.

1) Protein analysis is represented in Table 1 . The results showed that the application of Mn (T1) and B (T5) increased protein by $3.9 \%$ and $4.3 \%$, respectively, as compared to control. No significant changes were observed with $\mathrm{Cu}$ (T2) or $\mathrm{Zn}$ (T4) treatments, whereas, the application of these micronutrients in combination with CA resulted in a decrease in protein content in all treatment except in $\mathrm{T} 7$.

2) Oil content (Table 1) increased with $\mathrm{Cu}(6.4 \%), \mathrm{Zn}(3.8 \%)$, Mo (4.9\%) CA (6.2\%), $\mathrm{Cu}+\mathrm{CA}(7.6 \%), \mathrm{Zn}+\mathrm{CA}(4.5 \%), \mathrm{B}+\mathrm{CA}(4.8 \%)$ applications when compared to control. However, B treatment showed an increase in protein, while a decrease in oil content. 
Table 2. (SAS). Five fatty acids composition after chemical treatment where $\mathrm{C}$ is control and the rest of the chemicals are chlorides except $\mathrm{Mo}\left(\mathrm{MoO}_{3}\right)$ and Citric acid $(\mathrm{CA})$ and $\mathrm{B}$ (Boric acid), $\mathrm{H}_{3} \mathrm{BO}_{3}$.

\begin{tabular}{|c|c|c|c|c|c|}
\hline Treatments & Linoleic (18:3) & Linolenic (18:2) & Oleic (18:1) & Stearic & Palmitic \\
\hline C & $3.35 \mathrm{ef}$ & $49 \mathrm{f}$ & $38 \mathrm{bc}$ & $4.23 \mathrm{~cd}$ & $10.3 \mathrm{de}$ \\
\hline $\mathrm{T} 1(\mathrm{Mn})$ & $3.1 \mathrm{ef}$ & $49.2 \mathrm{f}$ & $37.8 \mathrm{bc}$ & $4.27 \mathrm{bcd}$ & $10.47 \mathrm{~cd}$ \\
\hline $\mathrm{T} 2(\mathrm{Cu})$ & $1.8 \mathrm{~h}(-46.3)$ & 49.9 ef & $41.1 \mathrm{a}(+8.2)$ & $4.0 \mathrm{fg}(-5.4)$ & $8.4 \mathrm{~h}(-18.4)$ \\
\hline T3 (Zn) & $4.35 \mathrm{~cd}(+29.9)$ & $49.8 \mathrm{f}$ & $37.4 \mathrm{bc}$ & $4.3 \mathrm{bcd}$ & $10.0 \mathrm{ef}$ \\
\hline $\mathrm{T} 4$ (Mo) & $4.35 \mathrm{~cd}(+29.9)$ & $51.0 \mathrm{cde}(+4.2)$ & 34.0 de $(-10.5)$ & $4.4 \mathrm{cb}$ & $10.8 \mathrm{bc}(+5.1)$ \\
\hline T5 (B) & & $49.5 \mathrm{f}$ & $40.8 \mathrm{a}(+7.4)$ & $3.9 \mathrm{~g}(-7.8)$ & $9.2 \mathrm{~g}(-10.7)$ \\
\hline T6 (CA) & 3.4 ef & $51.6 \mathrm{cde}(+5.3)$ & 33.5 e $(-12.0)$ & $4.38 \mathrm{~b}(+3.5)$ & $10.5 \mathrm{~cd}$ \\
\hline $\mathrm{T} 7(\mathrm{Mn}+\mathrm{CA})$ & $3.0 \mathrm{fg}$ & $50.4 \mathrm{def}$ & $36.3 \mathrm{~cd}$ & $4.2 \mathrm{de}$ & $9.75 f(-5.3)$ \\
\hline $\mathrm{T} 8(\mathrm{Cu}+\mathrm{CA})$ & $4.83 c(+44.0)$ & $52.33 \mathrm{abc}(+6.8)$ & $28.75 \mathrm{fg}(-24.3)$ & $4.2 \mathrm{de}$ & $11.3 \mathrm{a}(+9.7)$ \\
\hline T9 $(\mathrm{Zn}+\mathrm{CA})$ & $2.93 \mathrm{fg}$ & $50.1 \mathrm{ef}$ & $36.4 \mathrm{dc}$ & $4.2 \mathrm{de}$ & $10.5 \mathrm{~cd}$ \\
\hline $\mathrm{T} 10(\mathrm{Mo}+\mathrm{CA})$ & $5.75 \mathrm{~b}(+71.6)$ & $52.3 \mathrm{abc}(+6.7)$ & $29.4 \mathrm{f}(-22.7)$ & $4.18 \mathrm{de}$ & $11.2 \mathrm{ab}(\mathbf{+ 8 . 7})$ \\
\hline T11 (B + CA) & $3.43 \mathrm{def}$ & $52.4 \mathrm{f}$ & 32.7 e $(-14.0)$ & $4.18 \mathrm{de}$ & $10.23 \mathrm{de}$ \\
\hline
\end{tabular}

Notes: Means given within a column bearing the same letter like the control are not significantly different at $\mathrm{p}<0.05$. The numbers in the brackets with $\%$ are the percentage changes increase or decrease in seed composition.

3) The five fatty acids analyzed were palmitic (saturated, 16:0), stearic (saturated, 18:0), oleic (monounsaturated, 18:1), Linoleic (polyunsaturated, 18:2) and linolenic (polyunsaturated, 18:3) (Table 2). We have created structures to illustrate the structures of these 5 fatty acids, Figure 1 . The results from our different micronutrient treatments showed: $\mathrm{Cu}$ application decreased palmitic, stearic,and linolenic by $-18.4 \%,-5.4 \%$ and $-46.4 \%$, respectively, while increasing oleic acid by $+8.2 \%$. The $\mathrm{Zn}$ treatment increased linoleic acid by $+29.9 \%$ in seeds, while no significant changes were seen in other four acids. Mo treatment decreased oleic acid (18:1) by $-10.5 \%$, while increasing palmitic, linoleic, and linolenic by $+5.1 \%,+4.2 \%$ and $+29.9 \%$ respectively. $\mathrm{B}$ and $\mathrm{Cu}$ increased oleic acid by $+7.4 \%$ and $+8.2 \%$, respectively, and both elements decreased palmitic by $-10.7 \%$ and $-18.4 \%$; decreased stearic by $-7.8 \%$ and $-5.4 \%$, respectively.

Combination treatments: Chelating agent citric acid (CA) application increased stearic and linoleic by $3.5 \%$ and $+5.3 \%$, respectively. However, CA decreased oleic by $-12.0 \%$. Three of the five micronutrients which are $\mathrm{Cu}, \mathrm{Mo}$ and B when applied to the plants in combination with CA (T8, T10, and T11)decreased seed oleic acid content by $-24.3 \%,-22.7 \%$ and $-14.0 \%$, respectively. No significant changes were observed in Mn + CA (T7) Zn + CA (T9) treated groups compared with the control. The $\mathrm{Cu}+\mathrm{CA}$ (T8) and Mo + CA (T10) increased linolenic acid by $44.0 \%$ and $71.6 \%$, respectively. It is worthwhile to note that while increasing linolenic acid, these two same treatments (T8 and T10) decreased oleic by $-24.3 \%$ and $-22.7 \%$, respectively. In Figure 2, we have proposed a possible mechanism for such changes. 

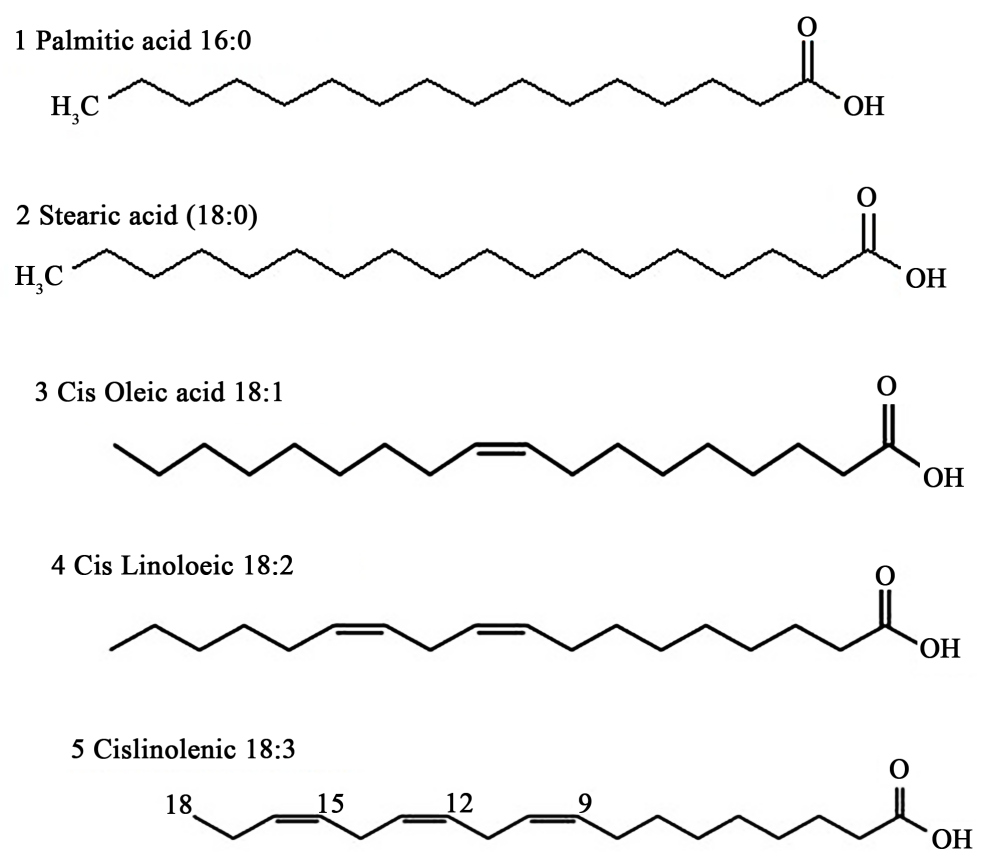

Figure 1. Pictures of five fatty acids studied in our studies.

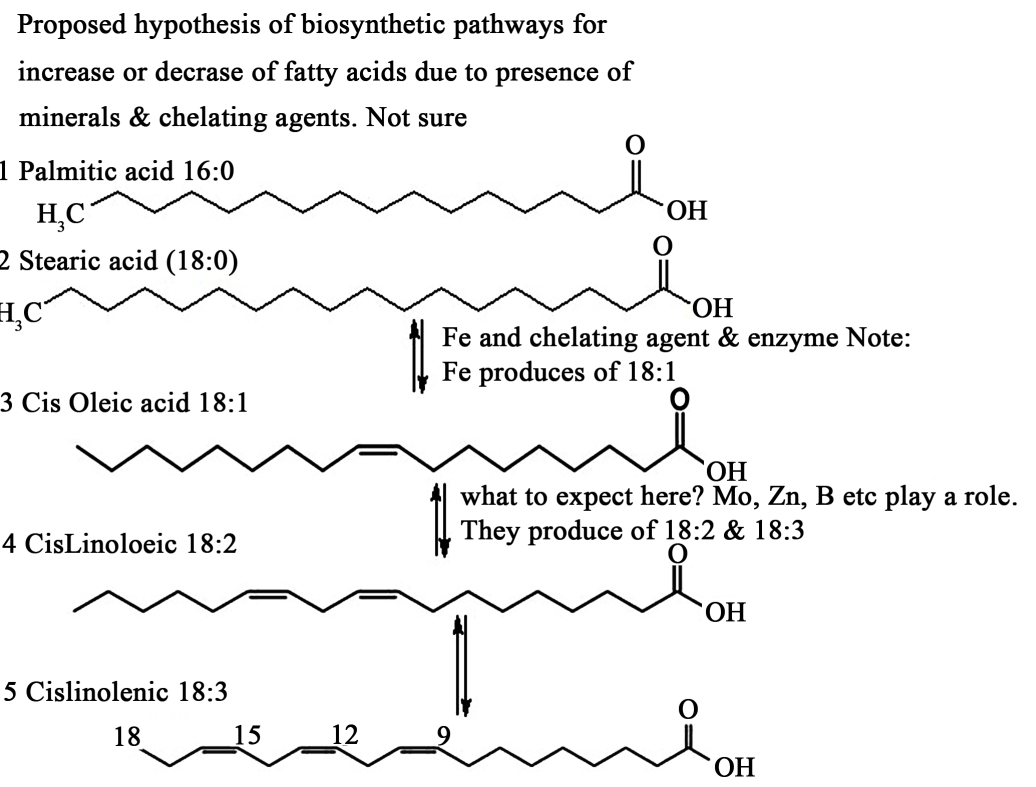

Figure 2. Proposed probable mechanism for formation of more of one over the other.

\section{Discussion}

In the present study we observed Mn and B applications increased protein by 3.9 and $4.3 \%$, respectively (Table 1 ). This was in accordance to earlier reports that they found application of B resulted in increase in protein, while decreasing oil content [2] [7]. They have also reported similar results of increase in protein by $\mathrm{Mn}, \mathrm{B}$, and $\mathrm{Zn}$ treatment. In our earlier study [16], B and $\mathrm{Cu}$ had increased nitrogen content in the seeds which might have affected protein increase in seeds. 
However, only B seems to have nitrogen and protein association. Whereas, $\mathrm{Zn}$ another essential micronutrient which participates in a wide variety of cellular processes, and is a key component [21] [22] of many enzymes and in protein synthesis, however, at the rate $\mathrm{Zn}$ and $\mathrm{Cu}$ was applied in the present study had no significant change on protein or fatty acids (Table 2). Seed oil was the only factor which showed an increase with $\mathrm{Zn}$ application. Again, Mo is another key component of two major enzymes in plants, nitrogenase and nitrate reductase. Several authors [23] [24] have concluded from their studies that Co and Mo significantly enhance protein contents of seeds. Another study [6] [25] also reports that Mo, similar to Fe, plays an important role in nitrogen fixation and photosynthesis. The present study did not show any increase in protein content at the rate Mo was applied in the soil. Since Mo is required in very small quantity, we need to find the optimum concentration and mode of application which might improve seed protein content.

The minerals ( $\mathrm{Mn}$ and $\mathrm{B}$ ) when applied alone, which showed positive effect on protein, whereas, had negative impact on protein when applied in combination with CA. The CA treatment might be either interfering with or making the metal ions unavailable for amino acid synthesis. Further studies of citric acid as an organic ligand role need to be investigated before we can derive any conclusion. The seed oil content, however, increased with most applications including $\mathrm{Cu}$, $\mathrm{Zn}, \mathrm{Mo}, \mathrm{CA}, \mathrm{Cu}+\mathrm{CA}, \mathrm{Zn}+\mathrm{CA}, \mathrm{B}+\mathrm{CA}$, and the increases were $6.4 \%, 3.8 \%$, $4.9 \%, 6.2 \%, 7.6 \%, 4.5 \%$ and $4.8 \%$, respectively. Hence, the micronutrient applications proved to be more effective in increasing oil content in soybean seeds.

The present comprehensive study, consisting of 5 micronutrient treatments, was carried out to evaluate the impact of nutrient applications on soybean seed composition (protein, oil, and fatty acids). In our earlier greenhouse experiment, Fe application had positive impact in the formation of oleic acid. Similar results were obtained in the present study with $\mathrm{Cu}$ and B treatments, with an increase in oleic acid by $8.0 \%$ and $7.4 \%$, respectively. The transition metals $\mathrm{Fe}, \mathrm{Cu}$ and p-block B have shown promise in increasing the oleic acid, while decreasing saturated palmitic and stearic acid. On the contrary, the metals in combination treatments $\mathrm{Cu}+\mathrm{CA}, \mathrm{Mo}+\mathrm{CA}$, and $\mathrm{B}+\mathrm{CA}$ decreased oleic by $-24.3 \%,-22.7 \%$ and $-14.0 \%$, respectively. However, $\mathrm{Cu}+\mathrm{CA}$ (T8) and Mo + CA (T10) increased linoleic acid by $6.8 \%$, and $6.7 \%$, as well as linolenic acid by 44.0 and $71.6 \%$, respectively, which again could be a desired quality in soybean seeds.

\section{Conclusions}

Soil application of micronutrients $\mathrm{Mn}$ and $\mathrm{B}$, under greenhouse conditions, increased protein content in soybean seeds. Application of CA and micronutrients in combination with $\mathrm{CA}$, however, failed to modulate seed protein content. Elements $\mathrm{Cu}, \mathrm{Mo}$, and $\mathrm{B}$ in combination with the chelator CA increased polyunsaturated linoleic and linolenic acid in seeds, which is again a desired quality in soybean seeds. We can, thus, conclude that micronutrient application might re- 
sult in modulating seed protein and oil contents, while CA in combination was found to increase polyunsaturated fatty acids.

\section{Acknowledgements}

We thank Sandra Mosley for seed analyses. This work was partially funded by the U.S. Department of Agriculture, Agricultural Research Service Project 6066-21220-012-00D. Mention of trade names or commercial products in this publication is solely for the purpose of providing specific information and does not imply recommendation or endorsement by the United States Department of Agriculture (USDA). USDA is an equal opportunity provider and employer.

\section{References}

[1] Ash, M. (2012) Soybean and Oil Seeds. United States Department of Agriculture Economic Research Service. http://www.ers.usda.gov/topics/crops/soybeans-oil-crops.aspx

[2] Wilson, R.F. (2008) Soybean: Market Driven Research Needs. In: Stacey, G., Eds., Genetics and Genomics of Soybean, Plant Genetics and Genomics: Crops and Models, Vol. 2, Springer, New York, NY. https://doi.org/10.1007/978-0-387-72299-3_1

[3] Potter, B. (2017) AGWEB.com Powered by Farm Journal.

[4] Ahmad, H.R., Aziz, T., Hussain, S., Akraam, M., Sabir, M., Khashi, S.U.R. and Hanafi, M.M. (2012) Zinc-Enriched Farm Yard Manure Improves Grain Yield and Grain Zinc Concentration in Rice Grown on a Saline-Sodic Soil. International Journal Agriculture and Biology, 14, 787-792.

[5] Gurmani, A.R., Din, J.U., Khan, S.U., Andaleep, R., Waseem, K., Khan, A. and Hadyat-Ullah. (2012) Soil Application of Zinc Improves Growth and Yield of Tomato. International Journal Agriculture and Biology, 14, 91-96.

[6] Zahoor, F., Ahmed, M., Mubeen, K., Siddqui, M.H., Rasheed, M., Ansar, R. and Mehmood, K. (2013) Soybean (Glycine max L.) Response to Micro-Nutrients. Turkish Journal of Field Crops, 18, 134-138.

[7] Asadi, A. and Mahmoodi, M. (2001) Investigation Trends and Its Consequences Mazandaran Province. The $7^{\text {th }}$ Soil Sciences Congress, Shahrkord, Iran. (In Persian)

[8] Frageria, N.K. (2007) Soil Fertility and Plant Nutrition Research under Field Conditions: Basic Principles and Methodology. Journal of Plant Nutrition, 30, 203-223. https://doi.org/10.1080/01904160601117887

[9] Sarkar, D., Mandal, B. and Kundu, M.C. (2007) Increasing Use Efficiency of Boron Fertilisers by Rescheduling the Time and Methods of Application for Crops in India. Plant Soil, 301, 77-85. https://doi.org/10.1007/s11104-007-9423-1

[10] Smith, D. (2010) Micronutrients Can Have a Macro Impact. Farm Journal, 134, 27-30.

[11] Cakmak, I. and Kutman, U.B. (2018) Agronomic Biofortification of Cereals with Zinc: A Review. European Journal of Soil Sciences, 69, 172-180. https://doi.org/10.1111/ejss.12437

[12] Ali, S., Khan, A.R., Arif, M., Mairaz, G., Fida, M. and Saiqq, B. (2008) Assessment of Different Crop Nutrient Management Practices for Yield Improvement. Australian Journal of Crop Sciences, 2, 150-157.

[13] Ghasemian, V. (2000) Evaluation of Micro Nutrient Elements Effects on Quality 
and Quantity of Soybean Seeds in East Azerbaijan. M.Sc. Thesis, Tarbiat Modarres University.

[14] Goli, M., Pande, M. and Bellaloui, N. (2012) Effects of Chelating Agents on Protein, Oil, Fatty Acids, and Minerals in Soybean Seed. Agricultural Sciences, 3, 517-523. http://www.scirp.org/journal/PaperInformation.aspx?paperID=20174\&publishStatu $\underline{s=2}$ https://doi.org/10.4236/as.2012.34061

[15] Simons, J.N., Swindler, R. and Benedict, H.M. (1961) Absorption of Chelated Iron by Soybean Roots in Nutrient Solutions. Physiology, 37, 460-466.

http://www.ncbi.nlm.nih.gov/pmc/articles/PMC549816/pdf/plntphys00427-0008.pd $\mathrm{f}$ https://doi.org/10.1104/pp.37.4.460

[16] Goli, M., Pande, M., Bellaloui, N. and Wrachien, D. (2015) Effects of Soil Applications of Micro-Nutrients and Chelating Agent Citric Acid on Mineral Nutrients in Soybean Seeds. Agricultural Sciences, 6, 1404-1411. https://doi.org/10.4236/as.2015.611136

[17] SAS (2001) SAS 9.1 TS Level 1M3, Windows Version. 5.1.2600. SAS Institute, Gary.

[18] Bellaloui, N. and Gillen, A.M. (2010) Soybean Seed Protein, Oil, Fatty Acids and Mineral Composition as Influenced by Soybean Corn Rotation. Agricultural Sciences, 1, 27-30. https://doi.org/10.4236/as.2010.13013

[19] Helrich, K. (1990) Method 988.05. 15th Edition, Official Methods of Analysis, The Association of Official Analytical Chemists Inc., Arlington.

[20] Helrich, K. (1990) Method 920.39. 15th Edition, Official Methods of Analysis, The Association of Official Analytical Chemists Inc., Arlington.

[21] Yasari, E. and Vahedi, A. (2012) Micronutrients Impact on Soybean (Glycine max (Merrill)) Qualitative and Quantitative Traits. International Journal of Biology, 4, 112-118. https://doi.org/10.5539/ijb.v4n2p112

[22] MacDonald, R.S. (2000) The Role of Zinc in Growth and Cell Proliferation. The Journal of Nutrition, 130, 1500S-1508S. https://doi.org/10.1093/jn/130.5.1500S

[23] Caliskan, S., Ozkaya, I.M.E., Caliskan, M.E. and Arslan, M. (2008) The Effects of Nitrogen and Iron Fertilization on Growth, Yield and Fertilizer Use Efficiency of Soybean in a Mediterranean-Type Soil. Field Crops Research, 108, 126-132. https://doi.org/10.1016/j.fcr.2008.04.005

[24] Campo, R.J., Araujo, R.S. and Hungria, M. (2009) Molybdenum Enriched Soybean Seeds Enhance Nitrogen Accumulation, Seed Yield Seed Protein Content in Brazil. Field Crop Research, 110, 219-224. https://doi.org/10.1016/j.fcr.2008.09.001

[25] Bennett, W.F. (1993) Plant Nutrient Utilization and Diagnostic Plant Symptoms. In: Bennett, W.F., Ed., Nutrient Deficiencies and Toxicities in Crop Plants, The APS Press, St Paul, 1-7. 